\title{
Makna kearifan lokal To Parenge dalam penyelesaian konflik lahan di Tana Toraja
}

\author{
The meaning of local To Parenge's authority in the resolution of land conflict \\ in Tana Toraja
}

\author{
Suparman Abdullah* \\ Departemen Sosiologi, Fakultas Ilmu Sosial dan Ilmu Politik, Universitas Hasanuddin \\ Makassar, 90245, Sulawesi Selatan, Indonesia \\ E-mail corresponding author: suparmanabdullah1@yahoo.com
Sultan
Departemen Sosiologi, Fakultas Ilmu Sosial dan Ilmu Politik, Universitas Hasanuddin Makassar, 90245, Sulawesi Selatan, Indonesia
E-mail: sultan.12@yahooo.com
Rano Saputra Matande
Departemen Sosiologi, Fakultas Ilmu Sosial dan Ilmu Politik, Universitas Hasanuddin Makassar, 90245, Sulawesi Selatan, Indonesia
E-mail: ranosmatande@gmail.com

\begin{abstract}
Abstrak
Pendekatan kearifan lokal merupakan salah satu manajemen yang efektif dalam resolusi konflik lokal. To Parenge merupakan salah satu bentuk kearifan lokal etnis Toraja yang dibentuk dan dipilih oleh beberapa keluarga pemilik tongkonan. To Parenge merupakan pemimpin representatif, yang bertanggungjawab atas kelangsungan dan pengembangan tongkonan (Tongkonan bagi komunitas etnis Toraja secara fisik merupakan bangunan dan secara sosial budaya merupakan simbol ikatan dan perekat keluarga). Kajian ini bertujuan untuk memperkenalkan potensi kearifan lokal To Parenge dalam peran sebagai manajemen penyelesaian konflik serta proses penentuan To Parenge dalam komunitas Toraja sebagai institusi yang berperan dalam menyelesaikan konflik/sengketa lahan. Riset ini menggunakan pendekatan kualitatif dalam mengungkap fenomena sosial dengan menggunakan data-data dari hasil wawancara mendalam dan observasi. Hasil penelitian menunjukkan bahwa (1) To Parenge merupakan salah satu bentuk kearifan local etnis Toraja, statusnya sebagai pemimpin informal diakui peranannya dalam menyelesaikan masalah sosial khususnya dalam kasus konflik/sengketa lahan; (2) To Parenge sebagai pemimpin merupakan institusi yang dibentuk oleh keluarga-keluarga pemilik tongkonan melalui proses kombongan (musyawarah); (3) To Parenge sebagai institusi lokal merupakan kerangka mediasi dalam manajemen konflik, di mana To Parenge berperan dalam menyampaikan dan memperjuangkan kepentingan bersama keluarga pemilik tongkonan dalam suatu wilayah lembang/desa. Dalam setiap lembang/desa terdapat beberapa tongkonan dan setiap tongkonan terdiri dari beberapa keluarga sebagai pemilik. To Parenge menjadi pemimpin/perwakilan dari beberapa keluarga sebagai pemilik tongkonan.
\end{abstract}

Kata Kunci: To Parenge; tongkonan, masalah sosial; manajemen konflik; keraifan lokal

\begin{abstract}
Local wisdom approach is one of effective management in local conflict resolution. To Parenge is one form of local ethnic Toraja which was formed and chosen by several families of tongkonan owners. To Parenge is a representative leader, responsible for the continuity and development of the tongkonan. (Tongkonan for the Toraja ethnic community is physically a building and social culture is a symbol of family bonding and adhesive). This study aims to introduce potential local wisdom To Parenge in the role of conflict resolution management as well as the process of determining To Parenge in the Toraja community as an institution that plays a role in resolving land conflicts/disputes. The results show that (1) To Parenge is one form of local ethnic Toraja wisdom, his status as an informal leader recognized his role in resolving social problems especially in the case of land conflicts/disputes; (2) To Parenge as a leader is an institution formed by the families of Tongkonan owners through the process of the Commonwealth (deliberation); (3) To Parenge as a local institution is a framework of mediation in conflict management, where To Parenge a role in delivering and championing the
\end{abstract}


interest of the family owner Tongkonan in a region of Lembang/village. In each Lembang/village there are several tongkonan and each tongkonan consists of several families as owners. To Parenge became a leader/representative of several families as owners of Tongkonan.

Keywords: To Parenge; tongkonan, social problems; conflict management; local

\section{Pendahuluan}

Setiap komunitas memiliki potensi kearifan local dalam berbagai bentuk seperti nilai budaya, tradisi dan praktek-praktek sosial (Aulia, 2010). Kearifan lokal dibutuhkan sebagai mediasi dalam menyelesaikan masalah sosial yang hadapi oleh komunitas. Konflik merupakan salah satu potensi masalah yang senantiasa hadir dalam setiap komunitas (Omuabor, 2000). Namun komunitas memiliki kekuatan dalam menyelesaikan setiap permasalahan yang dihadapi khususnya konflik (Verner, 1958).

Perspektif konflik memandang bahwa konflik adalah suatu fenomena yang sudah melekat dalam masyarakat (Marshall \& Gurr, 2005; Kriesberg, 2007). Masyarakat Indonesia yang plural memiliki potensi yang rentan untuk terjadinya konflik. Pluralisme Indonesia ditandai dengan adanya suku, agama, tradisi, sosial ekonomi dan budaya yang beragam. Pluralisme yang tinggi dalam masyarakat tersebut menjadi faktor penyebab kerentanan untuk terjadinya konflik (Stonequist, 1971; Conn, 1973; Smooha 1978; Osinubi \& Osinubi, 2006). Namun pluralisme yang tinggi pula menjadi kekuatan dalam menyelesaikan konflik yang terjadi seperti dalam bentuk kearifan lokal (Zamzami, 2016).

Konflik tidak bisa dihindari dari suatu komunitas, namun konflik perlu dikelola agar tidak menimbulkan kekerasan (Otite, 1999). Konflik terjadi jika permasalahan yang muncul di permukaan tidak dapat dicapai penyelesaiannya, sehingga kegagalan dalam mencapai kesepakatan ini berujung pada kekerasan fisik antara pihak-pihak yang berkonflik (Kolip, 2010).

Salah satu fenomena konflik yang terjadi di Kecamatan Mengkendek, Kabupaten Tana Toraja adalah konflik sosial karena terjadinya perbedaan atau pertentangan kedua belah pihak, yakni adanya saling klaim atas kepemilikan tanah tongkonan secarah penuh. Tanah tongkonan dalam masyarakat Toraja adalah tanah milik bersama dan digunakan untuk kepentingan seluruh anggota keluarga (Pakan, Pratiknjo \& Mamosey, 2018). Jadi semua anggota keluarga berhak untuk menggarap tanah tersebut.

Munculnya permasalahan karena masyarakat mulai memandang tanah tongkonan tersebut dari segi ekonomi. Hal ini dipicu oleh adanya rencana pemerintah untuk membangun bandar udara di lokasi tersebut yang membuat masyarakat kemudian berlomba-lomba untuk mendapat ganti rugi atas kepemilikan tanah tongkonan itu. Masyarakat Toraja memaknai, tanah tongkonan itu adalah tanah milik bersama dan seharusnya digunakan untuk kepentingan bersama tanpa ada yang berhak penuh atas tanah tongkonan tersebut (Rima, 2019).

Eksistensi To Parenge sebagai pemimpin dalam suatu komunitas Toraja sangat strategis dalam penanganan konflik. To Parenge' sebagai pemimpin informal memiliki fungsi untuk mengatur dan bertanggung jawab terhadap masalah yang terjadi dalam masyarakat (Mustafa, Arman \& Saudi, 2019; Panggarra, 2015). Seperti halnya konflik yang terjadi dalam masyarakat Toraja To Parenge' yang memiliki pengaruh diharapkan mampu menjadi pendamai terhadap kedua belah pihak yang berkonflik. Komunitas Toraja dalam menyelesaikan setiap permasalahan yang dihadapi menggunakan pendekatan kekeluargaan melalui kombongan (musyawarah) yang dipimpin oleh To Parenge' (Bigalke, 2005).

\section{Metode Penelitian}

Penelitian ini menggunakan pendekatan kualitatif dalam mengungkap fenomena sosial dengan menggunakan data-data dari hasil wawancara mendalam dan observasi. Jenis penelitiannya adalah studi kasus yakni pengkajian secara spesifik dan mendalam terhadap potensi kearifan lokal To Parenge serta perannya dalam menyelesaikan konflik local etnis Toraja. Sumber informasi adalah para tokoh masyarakat formal maupun informal. 


\section{Hasil dan Pembahasan}

Kedudukan To Parenge' dalam masyarakat Toraja adalah sebagai pemimpin dalam tongkonan yang dibawahinya. To Parenge' dibutuhkan perannya agar konflik yang terjadi dapat diselesaikan dengan baik untuk menciptakan rasa aman dalam komunitasnya. Untuk memahami mengenai To Parenge' studi ini menguraikan status dan kedudukannya dalam masyarakat Toraja.

\section{To Parenge' dalam masyarakat Toraja}

To Parenge' berasal dari dua kata yaitu "to" yang artinya orang dan "parenge" yang artinya pemikul tanggung jawab. Jadi To Parenge' adalah orang-orang yang dipilih langsung oleh masyarakat melalui mekanisme tertentu untuk menjalankan tugas seperti menyelesaikan konflik dalam masyarakat. To Parenge' diangkat dan diseleksi oleh masyarakat dalam suatu tongkonan berdasarkan garis keturunan, pengabdian dan penguasaan adat istiadat.

Masa jabatan seorang To Parenge' berakhir apabila yang bersangkutan telah meninggal dunia ataupun melakukan suatu pelanggaran yang berat. Jadi selama seorang To Parenge' masih hidup maka jabatannya juga akan tetap melekat dan seorang To Parenge' juga tidak dapat mengundurkan diri dari jabatannya. Adapun tugas dari To Parenge itu sendiri adalah sebagai berikut: a) Mengatur serta mengayomi aturan adat atas kesepakatan hasil kombongan dalam lingkup wilayah masing- masing; $b$ ) Menyelesaikan perselisihan antar anggota masyarakat dalam lingkup wilayah masing-masing; c) Memimpin dan mengatur serta bertanggung jawab atas pelaksanaan upacara adat dalam wilayah masing- masing; d) Memimpin pelaksanaan kerja gotong-royong (siarak) dalam penanggulangan bencana, pembuatan pondok upacara dan gotong-royong lainnya; e) Menjadi pengayom masyarakat (untarek lindopio). Berikut yang di jelaskan oleh LN (51 Tahun) di bawah ini:

“To Parenge' adalah tokoh- tokoh adat yang ditunjuk dalam suatu rumpun keluarga dalam setiap tongkonan untuk menjalankan tugas sebagai orang yang dituakan yang berfungsi untuk menata keberlangsungan hidup keluarga tongkonan"

Senada yang di utarakan oleh informan di atas, MB (64 Tahun) mengungkapkan sebagai berikut:

“To Parenge' sama halnya pemangku adat, To Parenge' adalah orang-orang yang dipilih dalam musyawarah adat dan dilantik ketika ada upacara adat rambu solo' (Upacara Kematian)"

To Parenge' sebagaimana yang dijelaskan sebelumnya adalah orang-orang yang memiliki tanggungjawab dalam masyarakat khususnya dalam mengatur tatanan kehidupan bermasyarakat. Dalam masyarakat pulat To Parenge' tidak hanya menjalankan tugasnya seorang diri. Dalam masyarakat Toraja terdapat pula lembaga adat yang terdiri dari tiga orang yang bekerja sama dengan To Parenge' dalam menyelesaikan masalah yang terjadi di masyarakat.

Untuk menyelesaikan konflik To Parenge' sebagai seorang pemimpin berperan sebagai hakim pendamai jika terjadi perselisihan seperti yang dikatakan oleh RK (57 Tahun) adalah:

\footnotetext{
"To Parenge' berfungsi sebagai hakim pendamai jika ada masalah dalam masyarakat. Dalam hal sengketa tanah lembaga adat dan To Parenge' berperan sebagai hakim pendamai. Jadi pihak yang berkonflik diadili oleh To Parenge' dan lembaga adat kemudian mengambil keputusan siapa yang benar dan salah selanjutnya mengadakan syukuran sebagai wujud syukur agar kedua belah pihak berdamai kembali. Jika pihak yang berkonflik tidak ingin berdamai maka keduanya diberi kesempatan untuk menempuh jalur hukum"
}

Sama halnya yang di katakan oleh PL (51 Tahun) bahwa To Parenge' memiliki tugas untuk memediasi pihak-pihak yang berkonflik dalam masyarakat khususnya tongkonan yang dibawahinya. Proses mediasi itu dilakukan untuk mencari jalan keluar agar konflik yang terjadi antar sesama anggota keluarga tongkonan dapat diatasi. Berikut yang dikatakan informan LN (64 Tahun): 


\begin{abstract}
“Jadi yamoto tu fungsinna To Parenge', lan misa' tongkonan nani To Parenge' yake den tu keluargana sisalah-salah yamo pasino'koranni to nahadiri tokoh ada' sola to ma'parentah na disipa'kadai. Yake tae' penyelesaian yake den ni pada 2 te'geran noka' ladipokadanni ko yamoto tu biasa pake jalur hukum/ jadi fungsi dari seorang To Parenge'/ dalam satu tongkonan yang ia bawahi jika ada keluarga yang bermasalah satu sama lain, maka To Parenge harus memanggilnya untuk duduk bersama yang juga dihadiritokoh adat untuk membicarakan persoalan tersebut. Jika tidak menemukan jalan keluar dimana masing-masing pihak bersikeras dengan pendapatnya, maka inilah biasa yang kemudian menempuh jalur hukum"
\end{abstract}

Seperti yang dikatakan informan RK dan LN bahwa penyelesaian masalah yang terjadi dalam masyarakat Toraja umumnya diselesaikan secara adat. Namun apabila pihak-pihak yang berkonflik tersebut tidak menemui jalan tengah maka ditempuh jalur hukum. Di tingkat pengadilan juga To Parenge' masih di minta keterangan tentang bagaimana proses penyelesaian masalah tersebut di tingkat adat. Jadi tetap ada rekomendasi dari To Parenge' dan tokoh adat ke pengadilan mengenai masalah yang terjadi.

Tugas dan fungsi dari To Parenge' yang kompleks menempatkannya pada kasta teratas dalam masyarakat Toraja yaitu tana' bulaan. Adanya pembagian kelas tersebut membuat To Parenge' juga mendapatkan perhargaan yang tinggi dalam lingkup keluarga tongkonan. Setiap tongkonan dipimpin oleh seorang To Parenge' yang diangkat menjadi pemimpin dalam tongkonan tersebut. Namun tidak semua orang dapat dijadikan sebagai To Parenge', ada beberapa syarat yang harus dipenuhi untuk menempati posisi tersebut. Seperti yang dikatakan oleh KS (53 Tahun) bahwa:

"To Parenge' dipilih berdasarkan musyawarah dalam keluarga tongkonan, tidak serta merta ditunjuk secara langsung. Jadi seorang To Parenge' itu ditunjuk berdasarkan garis keturunan serta ada beberapa pertimbangan-pertimbangan lain"

Pertimbangan- pertimbangan yang dijadikan acuan dalam menentukan seorang To Parenge' salah satunya adalah penguasaan adat istiadat, serta dirasa mampu untuk memimpin keluarga. Hal yang terpenting pula adalah seorang To Parenge' yang dipilih haruslah berasal dari tongkonan tersebut. Seperti halnya dikatakan oleh YP (52 Tahun):

"Seorang yang diangkat To Parenge' adalah orang-orang yang memiliki strata tinggi dan juga lahir dari kampung tersebut. To Parenge' adalah orang yang bisa memerintah"

Proses pergantian kepemimpinan To Parenge' umumnya berlangsung dengan baik, tidak ada kendala dalam menentukan siapa yang menjadi pemimpin dalam tongkonan tersebut. Tidak menjadi masalah pula ketika To Parenge' tinggal diluar dari tongkonan yang dibawahinya. Namun dalam hal pelaksanaan tugasnya sekali waktu To Parenge' dapat kembali ke daerah wilayah tongkonan untuk menjalankan tugas apabila terjadi masalah dalam masyarakat seperti konflik. Fungsi dari To Parenge' itu sendiri juga tidak hanya sekedar menyelesaikan masalah. Dalam masyarakat Toraja dikenal istilah bagi To Parenge' yaitu "to urrenge' sarona to buda" artinya menjadi aspirasi bagi masyarakat dan berusaha untuk mencari solusi. Setiap To Parenge' juga memiliki cakupan wilayah kekuasaan berdasarkan garis keturunan. Jadi To Parenge' tersebut bertanggungjawab atas tongkonannya masingmasing dalam hal menyelesaikan persoalan yang terjadi didalamnya.

\title{
Status To Parenge' dalam masyarakat Toraja
}

Keberadaan Tongkonan dalam masyarakat Toraja merupakan suatu bentuk tatanan hidup dalam bentuk persekutuan rumpun keluarga. Setiap tongkonan yang ada dalam masyarakat Toraja dipimpin oleh seorang pemimpin adat yang disebut dengan nama To Parenge'. Adapun fungsi dari tongkonan tersebut adalah sebagai wadah untuk membicarakan setiap persoalan yang menyangkut dalam tongkonan. To Parenge' sebagai pemimpin dalam tongkonan tersebut juga dibagi kedalam tingkatantingkatan yang berbeda antara satu dengan yang lain, tergantung dari tongkonan dimana To Parenge' tersebut berasal. Seperti halnya ketika seorang To Parenge' berasal dari tongkonan layuk (agung), maka kedudukannya, juga akan tinggi dari To Parenge' yang lain begitu pula sebaliknya. 
Salah satu contoh tongkonan yang ada dalam masyarakat Toraja adalah Tongkonan 10 di kelurahan Tampo, Kecamatan Mengkendek. Tongkonan 10 Kelurahan Tampo merupakan salah satu tongkonan yang masuk dalam area pembangunan bandar udara di Kecamatan Mengkendek yang memiliki struktur seperti Tabel 1. Kesepuluh tongkonan yang ada pada Tabel 1, masing-masing memiliki fungsi dan peran masing- masing. Begitu pula dengan kedudukannya, semakin di atas seorang To Parenge' menjabat maka semakin tinggi status sosial seseorang yang menjadi To Parenge' di dalamnya. Tongkonan 10 yang ada di Kelurahan Tampo, Kecamatan Mengkendek adalah salah satu tongkonan yang sebagian tanah tongkonan masuk dalam area pembangunan bandar udara di Kecamatan Mengkendek. Penguasaan atau kepemilikan atas tanah-tanah milik adat diperoleh dengan sejauh mana seseorang melaksanakan akan tanggung jawab terkait dengan harkat, martabat, dan kedudukan dalam suatu rumpun keluarga tongkonan.

Tabel 1.

Tongkonan 10 kelurahan tampo

\begin{tabular}{cccc}
\hline Tongkonan layuk & Matua ulu & Anak patalo & $\begin{array}{c}\text { Tongkonan } \\
\text { patulak/pelaksana adat }\end{array}$ \\
\hline $\begin{array}{c}\text { Tongkonan rante } \\
\text { tampo (penentu } \\
\text { kebijakan) }\end{array}$ & Tongkonan buntu & $\begin{array}{c}\text { Tongkonan tondok } \\
\text { tangnga (anak } \\
\text { patalo rante) }\end{array}$ & $\begin{array}{c}\text { Tongkonan tondok } \\
\text { bangla' }\end{array}$ \\
\hline $\begin{array}{c}\text { Tongkonan saruran } \\
\text { (wakil) }\end{array}$ & $\begin{array}{c}\text { Tongkonan } \\
\text { tanduk bulan }\end{array}$ & $\begin{array}{c}\text { Tongkonan rante } \\
\text { dollok (anak patolo } \\
\text { saruran) }\end{array}$ & Tongkonan dare'dek \\
\hline & & & Tongkonan guali \\
\hline & & & Tongkonan babangan \\
\hline
\end{tabular}

Sumber: Data primer

Tongkonan 10 Kelurahan Tampo terdiri dari: (1) Tongkonan Rante Tampo (penentu kebijakan), dengan To Parenge' Ruth Karurukan; (2) Tongkonan Saruran (wakil), dengan To Parenge' Ny. Batara Sosang; (3) Tongkonan Buntu, dengan To Parenge' Ambe' Banni; (4) Tongkonan Tanduk Bulan dengan To Parenge' Kamelus Sampe; (5) Tongkonan Tondok Tangnga (anak patalo rante) dengan To Parenge' M.R.Patila; (6) Tongkonan Rante Dollok (anak patolo saruran) dengan To Parenge' Hendrik Sallolo; (7) Tongkonan Tondok bangla' dengan To Parenge' Yoslina Malino; (8) Tongkonan Dare'dek dengan To Parenge' Ambe' Natan; (9) Tongkonan Babangan dengan To Parenge' Ambe' Ganti; (10) Tongkonan Guali dengan To Parenge' Y.Sampe.

Tongkonan bukan hanya sebagai wadah untuk mempersatukan keluarga, namun tongkonan juga merupakan tempat untuk menyelesaikan setiap masalah yang terjadi didalam lingkup keluarga tongkonan. Seperti Tongkonan 10 kelurahan Tampo dimana terdapat sepuluh tongkonan didalamnya juga memiliki fungsi dan kedudukan yang berbeda-beda. Ada tongkonan yang berfungsi sebagai pemimpin (tongkonan layuk) dan ada juga yang berfungsi sebagai pelaksana tugas misalnya dalam hal upacara adat. Berikut yang dikatakan oleh YP (52 Tahun) Tahun mengatakan bahwa:

"Dalam Kabupaten Tana Toraja sendiri ada banyak tongkonan yang berdiri. Tongkonan itu sendiri mempunyai arti khusus dan arti umum. Kalau secara umum tongkonan dalam segi bangunan adalah "banua pa'rapuan" yang menjadi pusat untuk menyelesaikan masalah dalam masyarakat. Selain itu tongkonan juga adalah wadah persekutuan keluarga. Dalam masyarakat tampo sendiri memiliki tongkonan yang memerintah yang terdiri dari 10 tongkonan. Masingmasing tongkonan ini memiliki To Parenge' yang menjadi pemimpin didalamnya"

Seperti yang dikatakan informan YP bahwa tongkonan dapat diartikan sebagai sebuah persekutuan yang memiliki struktur dan memiliki fungsi didalamnya. Selain itu tongkonan juga memiliki wilayah 
yang disebut tanah tongkonan yang mirip dengan hak ulayat. Adapun perbedaan diantara keduanya adalah Hak ulayat merupakan hak persekutuan yang bersifat teritorial (berdasarkan lingkungan daerah) atas tanah di dalam wilayah kekuasaannya. Sedangkan tanah tongkonan adalah hak sekelompok masyarakat adat yang bersifat geneologis (berdasarkan ikatan darah).

Dalam uraian dan pendapat yang dikatakan informan YP dapat disimpulkan bahwa To Parenge' sebagai pemimpin dalam tongkonan mempunyai status sebagai pemimpin yang berfungsi untuk menyelesaikan masalah- masalah yang ada dalam tongkonan.

\section{Peran To Parenge dalam penyelesaikan konflik sengketa Tongkonan pada pembangunan bandar udara di Kecamatan Mengkendek}

Sengketa tanah dalam kasus pembangunan bandar udara di Kecamatan Mengkendek, Kabupaten Tana Toraja diawali karena adanya saling mengklaim atas kepemilikan tanah serta tidak adil dalam pembagian ganti rugi sesama anggota keluarga tongkonan. Gambaran mengenaai adanya sengketa tanah tongkonan yakni adanya pengaduan pihak (orang/badan hukum) yang berisi keberatan-keberatan dan tuntutan hak atas tanah, seperti status tanah, batas-batas tanah dan status kepemilikan. Hal ini menuntut adanya penyelesaian secara hukum, baik dari aspek perdata maupun administrasi untuk memperoleh kepastian dan perlindungan hukum. Kasus sengketa tanah dengan modus yang beragam selama ini terjadi karena tidak adanya bukti autentik sebagaimana yang disyaratkan peraturan perundang- undangan.

Gejala peningkatan jumlah penduduk, kemajuan teknologi serta kemajuan ekonomi berpengaruh terhadap meningkatnya tuntutan dan kebutuhan atas tanah. Identifikasi dan administrasi penguasaan dan pemilikan tanah menjadi kendala dalam upaya memperoleh kepastian hukum dan keadilan dalam pendaftaran hak-hak atas tanah.

Proses pembayaran lahan seluas 225 hektare untuk pembangunan bandar udara di kecamatan Mengkendek Kelurahan Tampo masih belum tuntas. Dalam proses pembebasan lahan tersebut, pemerintah membentuk panitia 9 yang diketuai oleh Sekretaris Kabupaten Tana Toraja. Kemudian dibentuk juga satuan tugas (satgas) pembebasan lahan berjumlah 146 orang yang beranggotakan para tokoh masyarakat antara lain tokoh- tokoh adat, pejabat pemkab, lurah/kepala desa, aktivis LSM, wartawan dan pensiunan tentara.

Hasil kesepakatan antara pemerintah dan masyarakat mengenai biaya ganti rugi adalah Lahan basah/ sawah yang berlum bersertifikat dihargai Rp $35.000 / \mathrm{m} 2$, tanah kering yang belum memiliki sertifikat Rp 21.390/m2. Lahan basah bersertifikat Rp.40.250/m2 dan lahan kering bersertifikat Rp.26.737/m2. Selain tanah, ganti rugi juga diberikan kepada 31 jenis tanaman produktif yang ada diatas lahan.

Adapun kronologis pembayaran ganti rugi pada pembangunan bandar udara di Kecamatan Mengkendek, Kabupaten Tana Toraja: a) Sosialisasi rencana pembangunan bandar udara di Kecamatan Mengkendek; b) Pada saat rencana pemerintah untuk membangun bandar udara di Kecamatan Mengkendek, pemerintah sebelumnya mengundang para To Parenge' beserta masyarakat yang memiliki lahan di lokasi pembangunan bandar udara; c) Inventarisasi lahan; d) Dalam proses ini dilakukan penyampaian kepada masyarakat mengenai hasil pemetaan dan pengukuran lokasi bandar udara; e) Sosialisasi harga lahan; f) Sosialisasi harga dilakukan guna mencapai kesepakatan antara pemerintah dalam hal ini panitia 9 dan masyarakat mengenai harga tanah. Berikut yang dikatakan oleh informan LN (51 Tahun):

\footnotetext{
"Sebelum adanya rencana pembangunan bandar udara di lokasi tersebut, pemerintah memanggil para To Parenge', tokoh- tokoh masyarakat dan ada juga pemilik lahan yang diundang oleh pemerintah. Tujuan pemanggilan ini adalah untuk membicarakan rencana pembangunan bandara dan juga biaya ganti rugi bagi masyarakat yang lahannya masuk dalam pembangunan bandara"
} 
Pendataan lahan dilakukan oleh panitia 9 dengan mengajukan syarat bagi pemilik lahan untuk melengkapi data kepemilikan tanah berupa sertifikat tanah atau bukti kepemilikan lain yang dikenal masyarakat setempat. Panitia 9 melakukan verifikasi data kepemilikan tanah dengan melibatkan kantor pertanahan Tana Toraja dan pemilik lahan untuk selanjutnya mengumumkan hasil verifikasi. Proses pembayaran ganti rugi dilakukan secara bertahap oleh panitia 9. Namun kemudian proses pembayaran ganti rugi tersendat akibat adanya masalah seperti kasus korupsi yang melibatkan tim sembilan itu sendiri. Selanjutnya pembebasan lahan juga mengalami masalah seperti terjadinya konflik kepemilikan tanah dan tidak meratanya pembagian hasil ganti rugi sesama keluarga tongkonan.

Konflik juga terjadi karena dalam proses pembangunan Bandar udara tidak melibatkan masyarakat. Sebagaimana disampaikan oleh salah seorang informan KS (53 Tahun):

"Setelah adanya penetapan dari pemerintah mengenai lokasi bandar udara di kecamatan
Mengkendek, kami tokoh-tokoh masyarakat dipanggil. Tapi seiring berjalannya waktu dan
pembangunan bandar udara tersebut kami para tokoh-tokoh adat sudah tidak dilibatkan lagi. Jadi
ketika ada masalah yang terjadi sulit bagi kami untuk ikut campur tangan didalamnya"

Seperti yang dikatakan oleh salah seorang tokoh adat MB (64 Tahun) mengatakan bahwa:

\begin{abstract}
'La ma' kurre sumanga' ki na den te pembangunan tama lan tondok, cuman yamotu masalah kemudian muncul saba' yate biaya ganti rugi ladibagi rata raka sole te tau tu garap i te padang atau la'b buda te toampui padang. Jadi tae' iana permasalahakantu masyarakat te padangna di nani membangun yari te masalahganti rugi tu menjadi persoalan khususnya inde liu simbuang.(kami masyarakatnya sebetulnya setuju atas pembangunan bandara ini. Yang menjadi masalah kemudian adalah biaya ganti rugi karena ada tanah yang digarap oleh orang lain selama puluhan tahun kemudian masuk dalam lokasi pemabangunan bandara. Apakah uang ganti rugi ini kemudian harus dibagi dua 50:50 antara penggarap dengan pemilik lahan atau yang punya tanah mendapatkan uang yang lebih. Jadi tidak ada masalah jika tanah masyarakat ini digunakan untuk membangun, yang menjadi masalah disini adalah masalah ganti rugi)"
\end{abstract}

Permasalahan utama dari tanah tongkonan adalah. Pertama karena umumnya tanah tongkonan tidak memiliki sertifikat karena merupakan kepemilikan keluarga tongkonan secara kolektif. Kedua adalah ketidak jelasan batas-batas tanah tongkonan. Ketiga adalah ketidakjelasan mengenai pemilik yang sah mengakibatkan adanya saling mengklaim atas kepemilikan tanah. Seperti yang dikatakan oleh AR (54 Tahun) berikut ini. Menurut salah satu informan AR (54 Tahun) mengatakan bahwa:

"Jadi masalah yang terjadi di mengkendek itu adalah orang luar yang datang untuk mengacau. Mengklaim atas tanah yang ada akibat adanya kecemburuan sosial padahal dia bukan orang didalam kampung"

Konflik tanah tongkonan berpengaruh terhadap semakin memudarkan nilai-nilai dan norma- norma yang ada dalam masyarakat, pelaku konflik sudah tidak patuh lagi terhadap norma-norma dan aturan yang berlaku dalam masyarakat. Terjadinya konflik selain karena adanya perbedaan- perbedaan yang ada dalam masyarakat, akar persoalan dari konflik utamanya terjadi akibat disfungsi sosial. Artinya bahwa nilai-nilai dan norma-norma sosial yang ada di dalam struktur sosial tidak lagi ditaati, pranata sosial, dan sistem pengendaliannya tidak berjalan sebagaimana mestinya (Kolip, 2010).

Konflik bisa saja berdampak pada hancurnya nilai dan norma-norma dalam masyarakat atau bahkan sebaliknya akibat ketidak patuhan masyarakat terhadap nilai dan norma-norma maka terjadilah konflik. Konflik dapat membawa dampak negative dan positif dalam kehidupan masyarakat. Menurut L. Coser bahwa dampak positif dari konflik adalah di dalam masyarakat biasanyamengugah warga masyarakat yang semula pasif menjadi aktif dalam memainkan peranan tertentu didalam masyarakat. 
Sebagai seorang pemimpin tentunya To Parenge' memiliki peran dan tanggungjawab yang besar dalam masyarakat. Masyarakat yang dipandang sebagai arena konflik membutuhkan suatu penanganan apabila terjadi konflik agar tidak meluas. To Parenge' sebagai pemimpin dalam suatu kelompok mempunyai pengaruh besar untuk memediasi pihak yang berkonflik. Dalam kasus sengketa tanah yang terjadi di Kecamatan Mengkendek, To Parenge' juga memiliki andil dalam menyelesaikan konflik tersebut apalagi sebagai orang yang dituakan To Parenge' didengar oleh segenap rumpun keluarga terutama mereka yang terlibat dalam konflik.

Di kabupaten Tana Toraja dimana hukum adat masih kental dalam kalangan masyarakat, peranan tongkonan dibawah pimpinan oleh seorang To Parenge' masih kuat. Konsekuensi dari hal tersebut di atas yaitu bahwa semua tanah yang termasuk wilayah tongkonan adalah milik dari tongkonan yang bersangkutan dan pemanfaatannya diatur oleh To Parenge'.

Setiap permasalahan yang timbul sehubungan dengan tanah tongkonan diselesaikan secara musyawarah, seperti apa yang dikatakan oleh salah satu dari tokoh adat yaitu Bumbungan:

\begin{abstract}
“Sewaktu peranan tongkonan masih kuat, maka peranan dan tanggung jawab To Parenge' adalah sangat besar dan penting di dalam mengurus dan menyelesaikan persoalan tanah tongkonan berdasarkan pada peraturan yang istimewa bagi masyarakat Toraja. Setiap permasalahan diselesaikan secara musyawarah oleh masyarakat Toraja yaitu: "Ungkataku' aluk sola pemali, ungkasiri' totumampata" artinya takut kepada sanksi-sanksi moral yang berlaku dalam masyarakat dan malu terhadap Allah penciptanya"
\end{abstract}

Tongkonan 10 Kelurahan Tampo sebagai salah satu Tongkonan yang masuk dalam area pembangunan bandar udara. Kebutuhan lahan seluas 225 hektare untuk pembangunan bandara, 94 hektare diantaranya merupakan tanah dalam lingkup wilayah Tongkonan 10 Kelurahan Tampo.

Proses penyelesaian konflik yang dilakukan To Parenge' di Tongkonan 10 Kelurahan Tampo dilakukan dengan beberapa pendekatan diantaranya adalah mediasi. Untuk menyelesaikan suatu konflik yang terjadi dapat dilakukan tiga pendekatan dalam menyelesaikanya yaitu konsoliasi, mediasi dan arbitration (Nasikun 1988). Konsoliasi adalah suatu usaha untuk mempertemukan keinginan keinginan pihak-pihak yang berselisih, bagi tercapainya suatu persetujuan bersama, bagi pihak-pihak yang bersengketa ada kesempatan untuk mendiskusikannya melalui suatu lembaga tertentu. Mediasi penyelesaian konflik dalam bentuk pertemuan dilakukan oleh To Parenge pada bulan juli 2011. Pada rapat tersebut pihak-pihak yang berkonflik dihadirkan bersama dengan tokoh-tokoh adat yang ada di lembang tersebut.

Upaya To Parenge' dalam menyelesaikan masalah konflik yang terjadi mendapatkan kendala seperti yang dijelaskan oleh PL. Adanya keinginan masing-masing pihak untuk mendapatkan biaya ganti rugi secara penuh akhirnya tidak bisa terpenuhi. Jalan tengah yang kemudian dilakukan untuk menyelesaikan masalah tersebut adalah melalui jalur hukum. Upaya konsoliasi yang dilakukan To Parenge' bersama dengan aparat pemerintah dalam hal ini perangkat desa tidak membawakan hasil yang memuaskan. To Parenge dalam peranya dalam menyelesaikan konflik adalah melalui kondoslidasi, media dan arbitrasi. Pihak ketiga dalam hal ini adalah To Parenge' dimana fungsinya hanya sebagai perantara.

Pendekatan lain yang dilakukan secara kekeluargaan dalam menyelesaikan masalah konflik yakni dengan menelusuri asal usul kepemilikan tanah tongkonan dengan massulo nene'. Massulo nene' adalah sebuah bentuk penelusuran kepemilikan atas tanah dengan menelusuri sejarah tanah hingga sampai saat ini. Namun setelah diadakan mediasi kedua belah pihak, yang secara adat berhak atas tanah tongkonan yang masuk dalam area pembangunan bandar udara di Kecamatan Mengkendek. Adapun cara memperoleh tanah tongkonan tersebut melalui perkawinan dan ada juga yang dihibahkan (ditekkenan). 
Dalam hal penetapan hak atas tanah tongkonan adalah melalui To Parenge. Di mana hal tersebut dimusyawarakan secara adat untuk menelusuri asal-usul kepemilikan tanah yang dipersengketakan melalui massulo nene'. Penanganan konflik adalah suatu upaya perumusan suatu solusi atas konflik yang terjadi untuk mencapai kesepakatan bersama yang bisa diterima oleh pihak-pihak yang berkonflik. Sejalan dengan Fisher et al (2001) bahwa resolusi konflik adalah usaha menangani sebabsebab konflik dan berusaha membangun hubungan baru yang bisa bertahan lama diantara kelompokkelompok yang bersiteru.

Upaya yang dilakukan oleh To Parenge' serta tokoh-tokoh adat dalam menyelesaikan konflik tersebut kesepakatan kedua belah pihak bahwa masing-masing pihak yang mendapatkan uang ganti rugi mendapat potongan sebanyak 3\% dari total penerimaan uang ganti rugi yang kemudian akan diberikan kepada tongkonan untuk kepentingan bersama. Seperti yang dikatakan oleh KS (53 Tahun):

\begin{abstract}
"Dalam kasus bandara di Mengkendek kami tetap memperjuangkan, karena yang menjadi persoalan adalah ada pihak-pihak yang mengatakan bahwa tanah yang menjadi pembebasan untuk pembangunan bandara adalah tanah negara, tanah tongkonan dan ada juga yang mengatakan bahwa tanah tersebut adalah tanah pribadi. Tapi menurut saya sendiri sebenarnya itu adalah tanah tongkonan. Persoalan ganti rugi telah disepakati bahwa ada potongan 3\% dari total penerimaan ganti rugi yang diberikan kepada tongkonan"
\end{abstract}

Kendala yang dialami oleh To Parenge' dalam melakukan upaya perdamaian bagi pihak yang berkonflik adalah karena pihak yang berkonflik memilih jalur hokum atau pengadilan secara tertutup. Begitu pula yang dikatakan oleh salah seorang To Parenge' YP (52 Tahun):

\begin{abstract}
"Susah karena pihak yang berkonflik tersebut tidak mengakui bahwa tanah tersebut adalah tanah adat jadi To Parenge' tidak bisa masuk untuk mendamaikan hal tersebut. Selain itu ada pihakpihak yang menggugat ke pengadilan secara tertutup"
\end{abstract}

Faktor yang berpengarut terhadap peran To Parenge dalam menyelesaikan konflik adalah sebagai berikut: (1) Ada pihak-pihak yang menggugat para To Parenge', yakni masyarakat yang menerima ganti rugi serta pemerintah dalam hal ini tim 9 yang diketuai oleh sekertaris daaerah Tana Toraja ke pengadilan melalui LSM; (2) Pihak-pihak yang berkonflik tidak menghasilkan kesepakatan oleh karena masing-masing pihak merasa berhak penuh atas tanah yang menjadi objek sengketa; (3) Pihakpihak yang berkonflik merasa bahwa tanah yang menjadi objek sengketa adalah tanah perseorangan, bukan tanah adat maupun tanah negara.

\title{
Simpulan
}

To Parenge sebagai suatu bentuk kearifan lokal masyarakat Toraja berperan dalam menyelesaikan persoalan yang dihadapi oleh masyarakat termasuk peran memediasi penyelesaian konflik tanah tongkonan. To Parenge dalan menjalankan perannya menghadapi banyak hambatan khususnya dalam menyelesaikan konflik tanah tongokonan. Penyelesaian konflik yang tidak sampai tuntas dapat mengancam atau mempengaruhi tingkat ketaatan dan kepatuhan masyarakat terhadap nilai-nilai serta norma-norma sosial yang menjadi perekat integrasi. To Parenge masih memiliki keterbatasan dari segi sumberdaya manusia dalam menjalankan perannya, khususnya dalam menyelesaikan konflik tongkonan. To Parenge menyadari perannya dalam menyelesaikan konflik terbatas pada kearifan lokal dan tidak bisa melakukan intervensi kasus dalam ranah hukum positif. 


\section{Daftar Pustaka}

Aulia TOS \& Dharmawan AH (2010) Kearifan lokal dalam pengelolaan sumber daya air di Kampung Kuta. Sodality 4:335-346.

Bigalke TW (2005) Tana Toraja: A Social History of an Indonesian People. Singapura: NUS Press.

Conn PH (1973) Social pluralism and democracy. American Journal of Political Science 17 (2):237

Fisher S et al (2001) Mengelola Konflik: Keterampilan dan Strategi Untuk Bertindak Cetakan Pertama, Alih Bahasa S.N. Kartikasari, dkk. Jakarta: The British Counsil, Indonesia.

Marshall MG \& Gurr TR (2005) Peace and conflict 2005. Center for International Development and Conflict Management. College Park MD: University of Maryland.

Mustafa AE, Arman A \& Saudi NS (2019) Social status relationship to purchase of tedong bonga for the Community Toraja Tribes. IOP Conference Series: Earth and Environmental Science 247 (1).

Panggarra R (2015) Upacara Rambu Solo'Di Tana Toraja: Memahami Bentuk Kerukunan di Tengah Situasi Konflik. Makassar: Sekolah Tinggi Theologia Jaffray bekerjasama dengan Kalam Hidup.

Pakan MSL, Pratiknjo \& Mamosey WE (2018) Rumah Adat "Tongkonan" Orang Toraja Kabupaten Tana Toraja Propinsi Sulawesi Selatan. Holistik 22.

Rima G (2019) Persepsi mayarakat Toraja pada upacara adat Rambu Solo' dan implikasinya terhadap kekerabatan masyarakat di Kecamatan Makale Kabupaten Tana Toraja. Phinisi Integration Review 2 (2). doi: https://doi.org/10.26858/pir.v2i2.10000

Omuabor V (2000) Ethnic Conflicts - When Tribes and Tongue Differ in Ethnic Conflicts - Counting the Human Cost. News Africa (UK) Limited.

Osinubi TS \& Osinubi OS (2006) Ethnic conflicts in contemporary Africa: The Nigerian experience. Journal of Social Sciences 12 (2):101-114. doi:10.1080/09718923.2006.11978376

Otite O (1999) On Conflicts, their Resolution, Transformation, and Managements in Otite O and Alberts I. O. (eds.) Community Conflicts in Nigeria, Management Resolution and Transformation. Nigeria: Spectrum Books.

Smooha S (1978) Israel: Pluralism and conflict. USA: University of California Press.

Stonequist EV (1971) Comparative ethnic relations: A framework for theory and research. The ANNALS of the American Academy of Political and Social Science 393 (1):184-184.

Verner C (1958) Community conflict by James S. Coleman. Glencoe: The Free Press, 1957. Adult Education 8 (3):189-190. doi:10.1177/074171365800800312

Zamzami L (2016) Dinamika pranata sosial terhadap kearifan lokal masyarakat nelayan dalam melestarikan wisata bahari. Jurnal Antropologi: Isu-Isu Sosial Budaya 18 (1):57-67. 